\title{
Nursing textbooks' conceptualization of nurses' responsibilities related to the ideal of a holistic view of the patient: A critical analysis
}

\author{
Lise Cecilie Kleppe ${ }^{* 1,2}$, Kristin Heggen ${ }^{2}$, Eivind Engebretsen ${ }^{2}$ \\ ${ }^{1}$ Department of Social Work, Child Care and Social Policy, Oslo and Akershus University College of Applied Sciences, Oslo, \\ Norway \\ ${ }^{2}$ University of Oslo, Oslo, Norway
}

Received: July 1, 2015

DOI: $10.5430 /$ jnep.v6n3p106
Accepted: November 10, $2015 \quad$ Online Published: November 30, 2015

URL: http://dx.doi.org/10.5430/jnep.v6n3p106

\begin{abstract}
Objective: In nursing education, nurses are trained to perceive their patients as whole persons with mind, body, and spirit. This relates to the professional ideal of holism. This article focuses on how basic nursing textbooks conceptualize the ideal, when instructing students to understand their patients in particular ways.

Methods: We analyzed several basic nursing textbooks with regard to their characterization of a nurse's clinical and caring gaze. Further we looked for how they train nurses to take responsibility for the whole person. We scrutinized the included texts using narratological text analysis tools that particularly emphasize how texts present a specific perspective regarding described events. Results: Our analysis showed that nurses are expected to assume only a limited and technical responsibility for the sick body, while simultaneously assuming almost unlimited responsibility for the patient as a human being. We identified a lack of integration between the focus on the patient's medical condition and the nurse's responsibility to view the patient as a human being.

Conclusions: The identified lack of integration between taking responsibility for the patient as a human being and simultaneously focusing on the patient's medical condition highlights the failure of the analyzed textbooks to conceptualize how a nurse can provide holistic care.
\end{abstract}

Key Words: Nurse-patient relationships, Holistic care, Ideals, Responsibility, Textual analysis, Narratology

\section{INTRODUCTION}

Among professional helpers, viewing patients and users as whole persons is an important ideal. This concept of holism is valued within many helping professions, including teaching, social work, psychology, and nursing. The present study explored how expectations of holism are articulated in basic textbooks for nursing students in Norway. Although this topic is of importance beyond this national context and across various professions, the nursing profession claims to have a distinctive focus on understanding, knowing, and caring for the whole person. ${ }^{[1]}$ Thus, our interest in nursing textbooks as a case is based on both the uniqueness of the nursing profession and its commonality with other professions. ${ }^{[2]}$ Moreover, particularly in nursing, textbooks represent an important and underestimated resource for future professionals to attain an understanding of the expectations in their career path.

\footnotetext{
${ }^{*}$ Correspondence: Lise Cecilie Kleppe; Email: lceci@online.no; Address: Department of Social Work, Child Care and Social Policy, Oslo and Akershus University College of Applied Sciences, Oslo, Norway.
} 
Several studies have investigated how education prepares students for their comprehensive workplace responsibilities, and how nurses undertake their responsibilities. ${ }^{[3-8]}$ However, prior studies have not focused on how textbooks articulate, define, and justify a nurse's responsibility for addressing the patient as a whole person. It is of great interest to investigate how basic textbooks describe these expectations, and to examine how nursing students are trained to view patients and what perspectives are presented through the textbooks.

This study was guided by the following questions. How do the examined textbooks instruct nursing students to view patients? How do the textbooks characterize the nurse's gaze? And finally, what are the implications regarding the nurse's responsibility for the whole person?

\subsection{Background}

The nursing profession values the ideal of viewing patients as whole persons. This concept is part of the national curriculum for social sciences and health sciences, and strongly influences textbooks. ${ }^{[9]}$ Although the curriculum varies among different countries, there is an important correlation between the curriculum and textbooks within each local context.

A professional textbook presents the values and expectations of the profession, translated and operationalized into concrete knowledge that the student can study. On one hand, the textbook is a medium for knowledge and communication. On the other hand, it is an instrument for power and control $^{[9,10]}$ with power defined as a positive force producing knowledge. ${ }^{[11,12]}$ Thus, the textbook represents a powerful tool developed with the aim of implementing specific ideas $^{[13]}$ that are important for the profession. Fournier ${ }^{[14]}$ has described how values and ideas have a disciplinary effect on professionals, potentially governing their conduct from a distance. Helping professionals are expected to not only address the needs of their patients and clients, but to do this in a specific ways. Textbooks can thus serve to both promote learning and to present "horizons of expectations"[15] for professionals. Although studying textbooks is only one of many learning activities that students engage in throughout their education, the textbooks constitute an important resource from which professionals can attain a sense of identity and self-understanding. Since holism is central to nursing, we would expect the basic textbooks to address this topic and to guide nursing students in how to take responsibility in a holistic manner.

\subsection{Holism in nursing}

Placing importance on viewing a patient as a whole person can be traced back to the holistic roots of the nursing profession. ${ }^{[16]}$ In the late 1980 s and early 1990 s, the impor- tance of holism was emphasized in response to the medical model in which nursing was becoming increasingly focused on diseases and diagnoses. ${ }^{[16,17]}$ This medical model was questioned because of its reductionist characteristics, and failure to acknowledge the patient as a human being.

Although holism as a general concept is considered an important value in nursing, the precise definition of holism remains unclear. $\mathrm{Kim}^{[16]}$ has argued that it is more correct to refer to multiple holisms due to the separate but important aspects of this general concept. However, the separate holisms share the major ideas that the whole is more than the sum of its parts, and that the parts are interdependent and rely on mutual interaction. McEvoy and Duffy ${ }^{[18]}$ performed a content analysis of holism, and present the following working definition of holistic nursing practice, which we assume in the present study: "Holistic nursing care embraces the mind, body and spirit of the patient, in a culture that supports a therapeutic nurse/patient relationship, resulting in wholeness, harmony and healing. Holistic care is patient led and patient focused in order to provide individualized care, thereby, caring for the patient as a whole person rather than in fragmented parts".

Despite disagreement regarding the precise definition, the ideal of holistic nursing is not controversial, although its application to practice has been disputed. ${ }^{[8]}$ For professions that focus on treating people, a holistic view of the patients and clients is both a prerequisite and a goal with regard to the quality of the work performed. ${ }^{[19,20]}$ Several researchers have described how a patient's integrity is at stake during their contact with a nurse or doctor, and the professional's actions can be either caring or uncaring, and can either promote or violate the patient's integrity and dignity. ${ }^{[21-25]}$ From the patient's point of view, characteristics of a good nurse include an inextricable combination of attitude and competence. ${ }^{[26]}$ Patients report that they must be viewed as a whole person in order to feel confident and supported with regards to their healthcare. ${ }^{[27,28]}$

The demands for holism challenge professionals in a variety of ways. As their professional responsibility involves their personal qualities, professionals must draw on their own resources in their work. ${ }^{[29-31]}$ Kari Martinsen is a nursing theorist who examines nursing's holistic roots ${ }^{[32]}$ and the importance of viewing a patient as a whole person ${ }^{[33]}$ as an integrated part of professional nursing. Martinsen states the following: "Being a professional is to demand specialist knowledge that makes it possible to see the patient as a suffering human being and that safeguards his integrity. It challenges the competencies and humaneness of the professional in a balanced interaction that stems from a common fundamental experience of protecting and taking care of 
life" ${ }^{[34]}$ (p. 12, author's translation).

To avoid reducing the patient to an object, a professional must draw upon both expertise and humaneness. Holism within the field of nursing demands a specific professional responsibility to perform skilled acts aiming to protect the patient from objectification. ${ }^{[35]}$ Research shows that a professional's position close to a patient or client causes them to assume extended responsibility, even in situations where other professionals limit their responsibilities. Such extended responsibility can be conceptualized as fulfilling their mandate regarding viewing the patient as a whole person. ${ }^{[36-38]}$ Concerns have been raised that medical technology threatens the nurse's focus on the patient as a fellow human being. The positioning of technology between the nurse and the patient, and an excessively one-sided emphasis on technology, can reportedly lead the nurse to reduce the patient to an object. ${ }^{[39]}$

Some authors have been more critical regarding an emphasis on holism, claiming that this goal can be achieved to only a limited degree at the workplace. ${ }^{[40]}$ Thus, nursing education creates expectations about holistic and psychosocial nursing, but the specific nursing tasks involved in this practice are described to a limited extent. ${ }^{[41]}$ In particular, Allen has argued that a focus on the intimate emotional relationship between a nurse and patient does not reflect the nurse's actual work or the patient's needs, resulting in a tension between the job that they are educated to do and the job they actually perform. ${ }^{[3,4,42]}$ This mismatch between nursing ideals and nursing practice can lead to dissatisfaction among nurses. ${ }^{[41,43]}$ Research shows a lack of operationalization of requirements, and reveals the limited extent to which education can prepare professionals for the complex responsibilities they face in the workplace. ${ }^{[13,44]}$ Being professional includes many obligations, which sometimes conflict with each other, and education falls short of preparing nurses for the complex expectations that will be involved in their working life. ${ }^{[7,45,46]}$

To view a patient as a whole person, a nurse must be able to see the suffering human being in addition to the medical condition of the patient. These two factors are integrated in a holistic view of a patient. To safeguard this ideal, the nurse's gaze must be directed in specific ways. Textbooks are key resources for students with regards to understanding how to maintain this holistic gaze during encounters with patients. Such texts tell nursing students what will be expected of them as professionals. In a sense, nursing education tells a story about the profession that implies a certain way of seeing. The technique of narratology enables examination of the guiding or governing perspective in texts, and is a suitable method for the present study to investigate how the student's gaze is led, and what the texts bring in or out of their field of view.

\section{Methods}

\subsection{Materials}

In the present study, we analyzed the set of books entitled Grunnleggende sykepleie ${ }^{[47]}$ (Basic Nursing). The preface to Volume 1 states that these books address fundamental nursing and contain knowledge forming the basis for all nursing practice. The set comprises four volumes, organized to support use throughout the three years of nursing education. These books are used in most nursing training colleges in Norway ${ }^{[48]}$ and thus represent an influential work among pedagogical texts in nursing education in this country. Although the present study was conducted in the Norwegian context, it is also potentially of interest in other regions. Within any national context, textbooks are important information sources that present professional ideals to students. Moreover, the ideal of a holistic view of the patient is not limited to Norwegian nursing practices. Thus, our analysis of these Norwegian textbooks has clear theoretical applicability to other national contexts.

The analyzed volumes are not written by one single author but rather by a group of specialists. Although the members of this group hold only a selection of positions within a diverse field, they reflect a diversity of opinions and a shared understanding of the field of nursing, which makes the work an interesting source for our use.

The website grunnleggende-sykepleie.com makes the following statements about this set of books (author's translation). The series consists of four volumes. The four books form one entity but can also be used separately. Volume 1 focuses on the nurse's contact with the patient, where the individual interaction takes place. Volumes 2 and 3 present the knowledge that is necessary to help the patient's fundamental needs to be met, as well as topics that are of key importance in nursing, such as reassurance, hope, alleviating suffering, and coping. Volume 4 illuminates various perspectives of nursing theory that place nursing in a societal context.

Each of the four volumes includes clinical nursing narratives and patient narratives, as well as photographs and illustrations. As this article focused on responsibility in regards to the relationship between nurse and patient, some parts of the series were more central to the analysis. We more closely analyzed Volumes 1, 2, and 3 because they explicitly address this issue. Volume 4 is less relevant to our study since it mainly focuses on the social context, and thereby addresses aspects of nurses' professional responsibility other than that relating to encounters with patients. Such selection criteria 
are also quite common when dealing with other kinds of material, e.g., interviews.

In our analysis of the text, we first reviewed the entire set of books and noted the sections relevant to our research questions. These sections formed the basis for a preliminary categorization. The books contained striking variation regarding the presentation of and focus on the nurse-patient relationship, with this subject treated as central in some instances and irrelevant in others. Information from our initial review was used to select passages that were particularly useful for approaching the research question, and these extracts were carefully read. For example, the many patient cases were deemed particularly helpful for characterizing the books' approach to patients, as they represented a condensed portrayal of the "grand narratives" of nursing. Based on this careful reading, we selected specific quotations that were particularly suitable for elucidating our analytical points, with the aim of illustrating the entire diversity of writing techniques that were used to present the nurse's gaze. This selection was governed by a "saturation principle" that permitted the inclusion of as many quotations/extracts as we considered necessary to cover the entire range of analytical points. ${ }^{[49]}$

\subsection{Analysis methods}

Our analysis focused on how nursing students are instructed to view patients. We scrutinized the texts using narratological text analysis tools. ${ }^{[50,51]}$ Narratology involves the important theoretical assumption that telling implies a way of seeing, in that telling guides the reader's gaze in a particular direction and excludes other possible perspectives. Here we approached the books using the text analysis method of focalization. ${ }^{[52,53]}$ We were particularly interested in examining how the books guide the perspective of the reader (i.e., the student) in a particular direction.

We applied several terms from narratology to construe the professional awareness or perspective as it was presented in the textbooks. First, we distinguished between the writer and the narrator, with the latter being a point of view or a voice presented through the text as opposed to the actual person behind the text. It is important to recognize that the writer can assume different perspectives within the same text. Furthermore, the perspective can be explained either in the first-person form or in the third-person form from a point outside the story. The narrator can also allow people described in the text to directly present their story to the reader through different types of quotation techniques. ${ }^{[52]}$

Focalization entails limiting the presented field and the information put forward in the text. ${ }^{[51]}$ In contrast to the narrator's voice, focalization is identified by asking the question "Who

Published by Sciedu Press sees?" rather than "Who speaks?", and in many cases these answers differ. For example, a book can present the patient's viewpoint and thus assume an internal focalization without the patient being the spokesperson in the first-person form. In such instances, the perspective will shift between internal focalization and the external narrator's voice. In this manner, the book can create identification without turning over all control or all responsibility to the patient. The choice of focalization in the text is an important factor influencing the picture we are given of the nurse and her area of responsibility. Therefore it is also relevant to include in the analysis what is highlighted through the different kinds of focalization.

How a nurse views a patient is a gaze with certain characteristics, which can be established through direct definition or indirect presentation. ${ }^{[54]}$ Direct definitions characterize people with the use of adjectives, while indirect presentation characterizes people through references to actions, speech, or external features. Descriptions of both individual actions and repeated actions, and of what people say or think, can construct a nuanced picture of the people involved. Examination of the characteristics of the nurses in the text should enable the analysis to depict the ideal nurse.

By taking a narratological approach to analyzing the nursing field through textbooks, we ensured that our analysis was directed towards the events as narrated ${ }^{[52]}$ rather than events that occur in "reality". We did not want to study practical nursing, or to examine how the set of textbooks is read by students or applied in working life. The intent of our study was for the books to be an independent object of analysis. Thus, the continuous text was the starting point for our analysis, albeit in a somewhat extended sense due to our inclusion of illustrations and photographs. ${ }^{[10]}$ To avoid addressing this topic at the level of an imagined ideal, we focused on discussions of how a professional nurse is to "act in a professionally responsible manner"[55] particularly the specific ways in which a nurse is expected to understand and respond to a patient's needs in order to take responsibility for the whole person.

\section{RESUlts}

\subsection{Seeing the patient-the suffering human being}

The textbooks include numerous patient cases that are intended to help enhance the nurse's understanding. Close analysis of these cases illustrates how a nurse is expected to view the patient. The introduction to Volume 1 presents a narrative that is referred to by the different authors at several places throughout the set (Chapter 1, p. 18/vol. 1). In this narrative, the reader sees the nurse through the patient's gaze. The patient is lying in bed waiting for their morning personal 
care routine, and is anxious to see who will arrive to perform this routine since it sometimes leads to painful situations for this patient. The quotation below is somewhat abridged (author's translation):

Is it Kari, Siv, or maybe Torunn today? Torunn has such good, soft, warm hands. And she takes her time, touches me carefully, asks how I want things done, and lets me determine the pace of the job. If only you knew how important this is! It can decide the whole course of the day for me. Brusque and hard-handed touching can often trigger pain and lead to more suffering as the day goes on. Siv is also gentle, with her good, wise, and questioning gaze. I can almost sense that she knows how I really feel. She talks to me-and not only at me-and she also listens... One of the worst things I experience is nurses who do not consider my privacy and leave me lying here naked and undressed-sometimes even with the door to the corridor open. I never feel so helpless as I do then. Waiting for something that I have been promised at a certain time can be just as bad. It can be something as important as needing help to go to the toilet... Have you thought about that-how it can feel?

This text allows the patient to narrate from her sickbed by using internal focalization and a first-person narrative voice, such that the focus concurs with the character in the narrative. The patient relates their experiences and thoughts in the first-person form and in the present tense, describing an ideal of how the nurse should view the patient to a reader who is expected to master this art. This angle of approach enables description of the nurse's focalization from outside, and instruction of the nursing student from the patient's standpoint with phrases like "If you only knew..." and "Have you thought about...". Through the patient's point of view, the book presents characteristics of an ideal nurse's gaze when viewing the patient, using the terms good, wise, and questioning. The nurse's view of the patient is distinguished from the gaze of others in that it can see and understand the "real" aspects of the patient. A genuine nurse's gaze sees not only the surface-i.e., the patient's body-but also the patient's core or essence, allowing the nurse to recognize the patient as a suffering human being, which is part of the holistic view.

One recurrent theme in the set of textbooks is that when a nurse's gaze views the patient in a genuine way, it lends a personal quality to the nurse's care. In such relationships, nurses must share some piece of themselves to appear as human beings to the patient. Furthermore, an ideal manner of seeing deep into the patient is accompanied by good warm hands, and by making it clear that the nurse has time for the patient. In contrast, when a nurse does not truly understand how the patient feels, the gaze is considered bodiless and impersonal. In this sense, the narrative mentions "nurses" in a general sense, and passively refers to "something I have been promised".

Several passages within the set of textbooks suggest that medical knowledge and diagnoses can be perceived as interfering with the ideal nurse's ability to view the patient as a suffering human being. Here the texts describe the nurse's limitations vis-à-vis medicine, since the biomedical way of looking at the patient is not considered to be the nurse's domain. The example below is taken from the chapter Helse og sykdom (Health and illness), (Chapter 2, p. 65/vol. 1: Understanding the life world of sick people; author's translation):

Although medical knowledge is a prerequisite for contact with the patient, this knowledge is not always sufficient to understand the patient's situation. Sometimes it can even block or impede understanding between the patient and the healthcare worker. When contact with a patient is based on pre-defined categories, there is a risk that the patient will not have the opportunity to express what is important for him. In such situations, patients often describe a feeling of being ignored-they are neither seen nor heard...

At a doctor's surgery, the patient's medical history is discussed while the doctor's attention is largely directed at the PC screen. During hospital admissions, a form that must be completed can have an inhibiting effect when the nurse admits the patient. The categories on the form may dictate the nurse's agenda, taking attention away from the patient's main concerns...

The forms and specific tools that are used during patient examinations can be useful, but may simultaneously prevent the nurse from acquiring an overall picture of the patient.

Guided by instincts about the patient's condition, a nurse can direct attention to the patient's lifeworld during conversation... By allowing senses to control the direction of the interaction, a nurse can be liberated from the biomedical spectacles that point the gaze in a defined direction and that make no allowances for the patient's individuality. The nurse uses her/his senses and empathetic skills to reveal important aspects of the patient's experience of illness... (Chapter 2, p. 65-66/vol. 1)

Here the genuine nurse's gaze is characterized via comparison to "biomedical spectacles." It is expressed that nurses should not allow their attention to be limited by diagnoses or columns on a form, thus allowing their gaze to extend beyond the biomedical gaze that is guided "... in a defined direction". While the doctor merely sees the PC, the nurse's 
view can acknowledge the patient's individuality and construct an overall picture of the patient. The beginning of the extract describes the nurse's process of talking to and listening to the patient, so that she/he is seen and heard. The text then further elaborates on how the nurse must interpret the situation using her/his senses, deciphering the patient's words and visual cues. The nurse is described as having the inherent "skill" needed to recognize and uncover the truth of the patient's condition. This portrayal of the nurse-patient relationship is complementary, as the patient is passive and the nurse is active in the revelation process.

Another example in the text relates to issues of identity and self-worth, asking the question "How can we read the patient's situation so that we see and understand the patient as he experiences it?" and stating that "It is therefore imperative to practice reading and interpreting such impressions, in ourselves and others, as an important basis for evaluation." (Chapter 19, p. 141/vol. 3) Despite the focus on the patient's experiences, and on the view that differs from the biomedical spectacles, the patient is not participating in this interaction as a human being.

\subsection{Seeing the medical condition}

Part of the specialist knowledge required by nurses is the ability to see and address the sick body in addition to the suffering human being. However, when the texts address the practice of nursing, the patient as a human being disappears. The patient cases include one example covering the theme of liquids and nutrition, elimination, and breathing, which describes a completely different way of viewing the patient, and a completely different ideal nurse. In this example, the nurse's view is that of an "aware" eye. These texts are instructive and explanatory, with illustrations and photographs that provide step-by-step directions for performing a procedure. These directions include the recommendation "should" and the instruction "must".

When you take another person's pulse, you must not use your own thumb, as you would then risk counting your own pulse in addition to the patient's, resulting in a wrong measurement. In cases where it is difficult to feel (palpate) the pulse with your fingers, or if you have doubt about whether there is any circulation to an area, it can be advantageous to use a Doppler apparatus (see Figure 1). (Chapter 8, p. 17/vol. 2-author's translation)

In another example of a recommendation, it is stated that "Patients who smoke and who suffer from arteriosclerosis and peripheral ischemic pain should be encouraged to stop smoking." The presented patient cases no longer show the nurse through the patient's perspective. Instead external focalization is used to present the patient in the third person:

Published by Sciedu Press
A patient in the nursing home department has been listless and has coughed for some days. He has eaten and drunk little. He is now confined to bed, and his temperature is 39.5. There is a gurgling sound in his chest and his breathing is rapid with a frequency of between 30 and 40 respirations per minute. He experiences difficulty in coughing up the phlegm, which seems to be thick. His lips are cyanotic... Once oxygen treatment has been started, the patient's oxygen saturation rises to $93 \%$, which is satisfactory. (Chapter 9, p. 68/vol. 2-author's translation)

Although the reader does not know whose view is presented, the gaze is clearly professional, characterized by its observing and recording nature. This is a gaze placed in a context that depends on technology. Due to the implied importance of the measurements, the nurse views the patient in an inspecting, recording, and measuring manner. Since this professional gaze requires the help of technology, it seems that it can stand alone without any personal qualities. It is a scientific gaze, strongly contrasting with the gaze linked to the various qualities of the nurse. In these examples, the nurse does not see a suffering patient but rather a person experiencing difficulty in coughing up mucus, i.e., a technical problem. The patient is perceived as the sum total of a series of objective mechanisms: listless, coughs, eats, and drinks. The relevant characteristics in these cases are the "hard facts" that are detached from the patient's body and that can be discussed without regards to the specific patient. The language is technical and refers to measurements, such as 39.5 degrees and a breathing frequency of between 30 and 40 per minute.

When the nurse looks at the patient's body using instruments, such as the Doppler apparatus, it becomes irrelevant that both the patient and the nurse are human beings.

The nurse must observe and report the pain localization, degree, and duration. Allowing the patient to express himself can give the nurse important information about when and in what situations the pain arises, the frequency of the attacks, the duration, and the measures that normally help. The nurse uses this information to plan the patient's care. (author's translation)

The focus of these texts presents nursing as being detached from the person. In the described cases, neither the nurse nor the nurse-patient relationship is relevant. Instead, it is presented as only a means of acquiring more information, and actions are subordinated to treatment. The nurse's gaze is authoritarian, as shown in the phrase "allowing the patient to express himself".

Similarly, in the texts related to basic physiological needs, 
the ideal nurse does not see "the person as a whole" and the relationship with the patient is irrelevant. A passage states that "One can also recommend a shower rather than a tub bath. For nurses, it is natural to use the morning or evening personal care routine, showers, and other suitable situations to inspect the patient's skin" (author's translation). This described inspection requires the nurse to use a recording gaze to view the physical aspects of the patient.

The illustrations related to fundamental needs also fail to reflect a holistic view of the patient, instead focusing on body parts and supporting the limited recording gaze described in the corresponding texts. The provided photographs and illustrations show hands holding various pieces of apparatus. Neither the nurse nor the patient is commonly shown as a whole person. In one example, the use of the Doppler apparatus (Chapter 8, p. 31/vol. 2) is shown with an image of two feet in a bed and two white-clad arms that are sticking the measuring pen into a foot. The caption reads "Sometimes it may be necessary to use a Doppler apparatus to record the pulse." The nurse's gaze is here characterized as comprehensive but impersonal. Although the nurse sees the patient in depth with the help of the apparatus, the focus is on the blood measurements and oxygen saturation rather than on the whole patient.

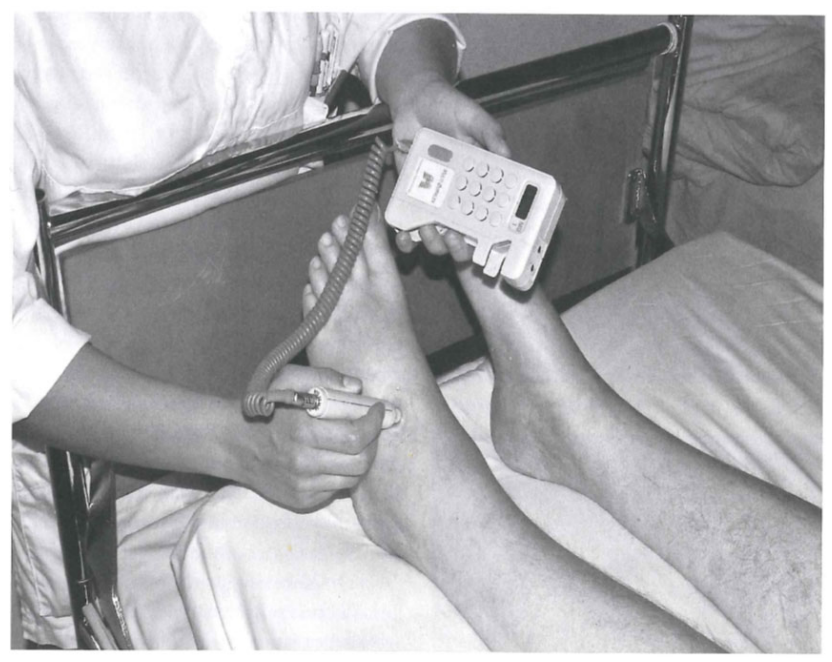

Figure 1. Sometimes it may be necessary to use a Doppler apparatus to record the pulse (Basic Nursing. 2008. p. 31/vol. 2)

\section{Discussion}

Our analysis of these textbooks revealed that the instruction focused separately on the patient's medical condition and on the patient as a human being. The texts could be considered to reflect the holistic view of the patient, since they present both the medical and the human aspects of the patient, and thus maintain the professional ideal of the nurse seeing the patient as a whole person. However, the books lack integration between the two focuses. Our analysis revealed that the ideal nurse's gaze is expected to see into the depth of the patient. However, there is an apparent distinction between the nurse's gaze when utilizing instruments and apparatus, and the gaze that views the patient in depth applying personal skills and empathy. The present findings reveal that the textbooks portray the ideal responsible nurse in two very different ways.

When the nurse examines the patient using instruments, the gaze is highly task-oriented and detached from the humanity of both the nurse and patient. In this situation, the patient-nurse relationship is irrelevant and the gaze is of a technical, scientific, and recording nature. However, research suggests that it is essential from the patient's perspective to be viewed as a whole person, in order to feel confident and supported with regards to health promotion. ${ }^{[27,28]}$ Furthermore, qualities in the personal relationship between a nurse and patient enable the nurse to meet the patient's needs and help them to endure the uncertainty. ${ }^{[56]}$

The impersonal gaze does not see the individual patient, but only the diagnoses or the sick body, which is the same distinction criticized in the field of biomedicine. The use of various measuring instruments is described as a nursing action involving professional competence independently of personality, with focus placed on the relationship between the nurse and the instrument. Viewing the patient in this manner is not conducive to holistic care, as the nurse's responsibility is limited to the patient's physical condition and biomedical parameters.

In contrast, when the nurse's gaze includes both personal competence and skills, it draws upon who the nurse is. Beedholm Poulsen previously analyzed textbooks from 1870 to 1956 with regards to their explicit discussion of the nurse's subjectivity. ${ }^{[57]}$ Paulsen claims that this was never discussed in textbooks for medical students. Our own analysis shows that the present day discourse of nursing remains characterized by this tendency to introspection. This view of the patient enables the nurse to see who the patient "really" is, implying a somewhat limitless gaze that reveals the core of the patient. However, this gaze leaves no room for the patient to participate in the relationship as a subject, leaving the nurse to make a nursing diagnosis in the same unilateral manner as the texts criticize the doctor for making his medical diagnosis. Furthermore, the language in the text is instrumental, such that it can be adapted to a biomedical framework. ${ }^{[30]}$ Thus, the gaze that is initially described as participant-oriented and exploratory grows to be of a recording nature. With 
regards to the nurse's responsibility to viewing the patient, the diagnostic perspective disappears and the nurse becomes responsible for some unlimited insight into the depth of the patient.

\section{Conclusion}

The importance of textbook analysis is supported by the textbooks' function as a mediator of professional ideals and their impact on the students' understanding of their future responsibilities. The present analysis aimed to examine how the textbooks stated that a nurse should see the patient, as well as the implications of this gaze with regards to the nurse's responsibility. Our findings revealed that the texts present separate descriptions of seeing the medical condition and seeing the patient as a human. The lack of integration between these two gazes leads to poor conceptualization of how a nurse should act while performing nursing tasks. On one hand, impersonal nursing behavior is described, implying that the nurse has a limited responsibility for the body. On the other hand, personalized nursing behavior is described, in which the nurse has a limitless responsibility for identifying undefined human elements within the patient. Forming a consistent integration of these two extreme characterizations could enable them to moderate each other, and thus construct a model of holistic care and medical responsibility with a meaning that extends beyond the physical aspects of the patient without becoming limitless. Such a model could further provide the nurse with a better platform when negotiating her responsibilities ${ }^{[28,59]}$ in specific work situations.

One common element of viewing the patient as a human being and only seeing the medical diagnoses is that both gazes allow the nurse to make a nursing diagnosis without the patient participating as a subject. The lack of allowance for patient participation implies that care cannot become patientled, which is a desired characteristic of holistic nursing. Furthermore, this restriction is not conducive to a therapeutic relationship between the nurse and the patient. In this setting, expertise and responsibility are entities linked to the nurse rather than relational phenomena. Anne Edward proposes an expanded understanding of what an expert professional is, stating that professional specialist knowledge further requires the capacity to recognize how others understand and interpret a situation, and to align one's own understanding to theirs. ${ }^{[60]}$ Such a relational conceptualization of expertise would recognize the patient's perspective, and allow it to be part of the basis of the nurse's assessment, in addition to the nurse's competence and personal skills.

It should be noted that the presently analyzed textbooks have been revised since completion of this text analysis, and the content may have been altered.

\section{CONFLicts OF INTEREST Disclosure}

The author declares that there are no competing interests.

\section{REFERENCES}

[1] Brockopp DY, Hastings-Tolsma MT. Fundamentals of Nursing Research. Sudbury, United States Jones and Bartlett Publishers, Inc; 2003.

[2] Stake RE. The art of case study research. Thousand Oaks, Calif.: Sage; $1995.175 \mathrm{p}$.

[3] Allen D. Re-reading nursing and re-writing practice: Towards an empirically based reformulation of the nursing mandate. Nursing Inquiry. 2004; 11(4): 271-83. PMid:15601415 http://dx.doi.o $\mathrm{rg} / 10.1111 / \mathrm{j} .1440-1800.2004 .00234 . \mathrm{x}$

[4] Allen D. What do you do at work? Profession building and doing nursing. International Nursing Review. 2007; 54(1): 418. PMid:17305956 http://dx.doi.org/10.1111/j.1466-765 $7.2007 .00496 . x$

[5] Lindh IB, Severinsson E, Berg A. Exploring student nurses' reflections on moral responsibility in practice. Reflective Practice. 2008; 9(4): 437-48. http://dx.doi.org/10.1080/146239408 02431713

[6] Lindh IB, Severinsson E, Berg A. Moral responsibility: A relational way of being. Nursing Ethics. 2007; 14(2): 129-40. http: //dx.doi.org/10.1177/0969733007073693

[7] Karseth B, Solbrekke TD. Characteristics of graduate professional education: expectations and experiences in psychology and law. Lon- don Review of Education. 2006; 4(2): 149-67. http://dx.doi.o $\mathrm{rg} / 10.1080 / 14748460600855252$

[8] Tyer-Viola L. Social Responsibility of Nursing: A global perspective. Policy Politics Nursing Practice. 2009; 10(2): 110-9. PMid:19696088 http://dx.doi.org/10.1177/1527154409339528

[9] Skrunes N. Lærebokforskning: en eksplorerende presentasjon med særlig fokus på kristendomskunnskap, KRL og religion og etikk. [Textbook research; an explorative presentation focusing on Christianity, religion and ethics]. Oslo: Abstrakt forl.; 2010. 322 p.

[10] Selander S. Pedagogiska texter och andra arteffakter för kunskap och kommunikation. [Pedagogical texts and other artifacts for knowledge and communication]. SOU. 2003; 15.

[11] Foucault M. Viljen til viten. [The will to truth]. Oslo: Exil Forlag; 1999. $198 \mathrm{p}$.

[12] Vågan A, Grimen H. Profesjoner i maktteoretisk perspektiv. [Professions in the perspective of power theory]. Profesjonsstudier [The study on professions]. Oslo: Universitetsforl.; 2008. 411-28.

[13] Fauske H, Kollstad M, Nilsen S, et al. Utakter: om helse- og sosialfaglig kompetanse i utdanning og praksis. [Out of step: the competencies of Health and social work in education and praxis]. Oslo: Gyldendal akademisk; 2006. 238 p.

[14] Fournier V. The appeal to "professionalism" as a disciplinary mechanism. Sociological Review. 1999; 47(2): 280-307. http://dx.doi . org/10.1111/1467-954X.00173 
[15] Knudsen SV, Aamotsbakken B, Skjelbred D. Tekst i vekst: teoretiske, historiske og analytiske perspektiver på pedagogiske tekster. [Growing texts; theoretical, historical and analytical perspectives on pedagogical texts]. Texts in . Oslo: Novus; 2007. 247 p.

[16] Kim H. The concept of holism. In: Kim H, Kollak I, editors. Nursing Theories: Conceptual and Philosophical Foundations: Springer; 2006. 89-108 p.

[17] Smart F. The whole truth? Nursing Management - UK. 2005; 11(9): 17-9.

[18] McEvoy L, Duffy A. Holistic practice - aconcept analysis. Nurse Education in Practice. 2008; 8(6): 8. PMid:18362085 http://dx.d oi.org/10.1016/j.nepr.2008.02.002

[19] Moos L, Krejsler J, Fibæk LP, et al. Relationsprofessioner: lærere, pædagoger, sygeplejersker, sundhedsplejersker, socialrådgivere og mellemledere. [Relational professions - teachers, educatiors, nurses, health care workers, social workers and middle managers]. København: Danmarks Pædagogiske Universitets Forlag; 2008.

[20] Rønnestad MH. Profesjonell utvikling. [Professional development]. Profesjonsstudier [The study on professions]. Oslo: Universitetsforl.; 2008. 279-94 p.

[21] Agledahl KM, Gulbrandsen P, Førde R, et al. Courteous but not curious: how doctors' politeness masks their existential neglect. A qualitative study of video-recorded patient consultations. Journal of Medical Ethics. 2011; 37(11): 650-4. PMid:21610269 http: //dx.doi.org/10.1136/jme.2010.041988

[22] Halldorsdottir S. The dynamics of the nurse-patient relationship: Introduction of a synthesized theory from the patient's perspective. Scandinavian Journal of Caring Sciences. 2008; 22(4): 64352. PMid:18803604 http://dx.doi.org/10.1111/j.1471-6 $712.2007 .00568 \cdot \mathrm{x}$

[23] Heijkenskjöld KB, Ekstedt M, Lindwall L. The patient's dignity from the nurse's perspective. Nursing Ethics. 2010; 17(3): 31324. PMid:20444773 http://dx.doi.org/10.1177/096973301 0361444

[24] Söderberg S, Olsson M, Skär L. A hidden kind of suffering: female patient's complaints to Patient's Advisory Committee. Scandinavian Journal of Caring Sciences. 2012; 26(1): 144-50. PMid:22011334 http://dx.doi.org/10.1111/j.1471-6712.2011.00936.x

[25] Widar M, Ek AC, Ahlström G. Caring and uncaring experiences as narrated by persons with long-term pain after a stroke. Scandinavian Journal of Caring Sciences. 2007; 21(1): 41-7. PMid:17428213 http://dx.doi.org/10.1111/j.1471-6712.2007.00449.x

[26] Rchaidia L, Dierckx de Casterlé B, De Blaeser L, et al. Cancer Patients' Perceptions of the Good Nurse: a Literature Review. Nursing Ethics. 2009; 16(5): 528. PMid:19671641 http://dx.doi.org/1 $0.1177 / 0969733009106647$

[27] Giske T, Gjengedal E, Artinian B. The silent demand in the diagnostic phase. Scandinavian Journal of Caring Sciences. 2009; 23(1): 1006. PMid:19250452 http://dx.doi.org/10.1111/j.1471-671 2.2008.00595.x

[28] Takman CAS, Severinsson EI. A description of health care professionals' experiences of encounters with patients in clinical settings. Journal of Advanced Nursing. 1999; 30(6): 1368-74. http: //dx.doi.org/10.1046/j.1365-2648.1999.01235.x

[29] Hem MH, Heggen K. Being professional and being human: one nurse's relationship with a psychiatric patient. Journal of Advanced Nursing. 2003; 43(1): 101-8. PMid:12801401 http://dx.doi.o $\mathrm{rg} / 10.1046 / \mathrm{j} .1365-2648.2003 .02677 . \mathrm{x}$

[30] Måseide P. Profesjonar i interaksjonsteoretisk perspektiv [Professions in an interactionistic perspective]. Profesjonsstudier. Oslo: Universitetsforl.; 2008. 367-85 p.
[31] Nygren P. Handlingskompetanse: om profesjonelle personer. [Competencies of action: about professional persons]. Oslo: Gyldendal akademisk; 2004. 386 p.

[32] McElligott D, Gershenson TA. Nourishing Nursing's Holistic Roots. Creative Nursing. 2004; 10(1): 12-3. PMid:15301344

[33] Kupferberg F. Kald eller profession?: at indtræde i sygeplejerskerollen. [A calling or a professions? to enter the role of the nursen]. København: Nyt Nordisk Forlag Arnold Busck; 1999. 200 p.

[34] Martinsen K. Øyet og kallet. [The eye and the calling]. Bergen: Fagbokforl.; 2000. 173 p.

[35] Abbott A. The system of professions: an essay on the division of expert labor. Chicago: University of Chicago Press; 1988. 435p.

[36] Kroken R. Forvandling av ansvar: en utvidet casestudie av barnevernarbeideres handlingsbetingelser i velferdsstaten. [Tranformation of responsbility: an extended case study of child welfare workers conditions for action in the welfare state]. Trondheim: Norges teknisknaturvitenskapelige universitet; 2012.

[37] Olsvold N. Ansvar og yrkesrolle: om den sosiale organiseringen av ansvar i sykehus. [Responsibility and professional role; about the social organization of responsibility in hospital]. Oslo: Unipub; 2010.

[38] Vike H, Bakken R, Brinchmann A, et al. Maktens samvittighet: om politikk, styring og dilemmaer i velferdsstaten. [The conscience of power: politics, governance and dilemmas in the welfare state]. Oslo: Gyldendal akademisk; 2002. 240 p.

[39] O'Keefe, McCarthy S. Technologically - mediated nursing care: the impact on morals agency. Nursing Ethics. 2009; 16(6): 78696. PMid:19889918 http://dx.doi.org/10.1177/096973300 9343249

[40] Vareide PK. Stykkevis og helt: sykepleieres arbeidsoppgaver, kompetanse og yrkesidentitet i sykehus. [Bits and wholes; nursing tasks, competencies and identity in hospitals]. Trondheim: NIS helsetjenesteforskning; 2001. 84 p.

[41] Norvoll. Gap mellom utdanning og yrke [Gap between education and occupation]. Sykepleien. 2002; 90(5).

[42] Allen D, Pilnick A. The Social organisation of healthcare work. Malden, Mass.: Blackwell; 2006. 192 p.

[43] Dingwall C. The implications of Healthcare reforms for the profession of nursing. Nursing Inquiry. 2001; 8: 64-74. http://dx. doi . org/10.1046/j.1440-1800.2001.00100.x

[44] Smeby JC, Mausethagen S. Kvalifisering til "velferdsstatens yrker". [Qualification to "the welfare state professions"]. 2011.

[45] Solbrekke TD, Karseth B. Professional Responsibility - An Issue for Higher Education? Higher Education. 2006; 52(1): 95-119. http://dx.doi.org/10.1007/s10734-004-5762-5

[46] Tveit B. Ny ungdom i gammelt yrke: en studie av sykepleierstudenters motivasjon og fagidentitet i møte med en tradisjonstung utdanning. [New youth in an old profession: a study of nurse student's motivation and professional identity in the face of a traditional education]. Oslo: Høgskolen i Oslo, Senter for profesjonsstudier; 2008.

[47] Kristoffersen NJ, Nortvedt F, Skaug EA. Grunnleggende sykepleie [Basic Nursing]. Oslo: Gyldendal akademisk; 2005.

[48] Bakken R. På leting etter kjønn i sykepleiefaglig pensumlitteratur [Searching for gender in nursing litteratur]. Porsgrunn: Høgskolen i Telemark; 2010. $74 \mathrm{p}$.

[49] Glaser BG, Strauss AL. The discovery of grounded theory: strategies for qualitative research. New York: Aldine de Gruyter; 1967.

[50] Genette G. Narrative discourse. Oxford: Basil Blackwell; 1980. 285 p.

[51] Genette G. Narrative discourse revisited. Ithaca, N.Y.: Cornell University Press; 1988.175 p. 
[52] Aaslestad P. Pasienten som tekst: fortellerrollen i psykiatriske journaler : Gaustad 1890-1990. [The patient as text: the narrator role in psyciatric journals]. Oslo: Universitetsforl.; 2007. 207 p.

[53] Bal M. Narratology: introduction to the theory of narrative. Toronto: University of Toronto Press; 2009. XIX, 264 p.

[54] Lothe J. Fiksjon og film: narrativ teori og analyse. [Fiction and film: narrativ theory and analysis]. Oslo: Universitetsforlaget; 1994. 268 p.

[55] Solbrekke TD, Sugrue C. Professional responsibility - back to the future. In: Sugrue C, Solbrekke T. D, editors. Professional responsibility new horizons of praxis: Routledge; 2011. 11-28 p.

[56] Cloyes KG. Agonizing care: care ethics, agonistic feminism and a political theory of care. Nursing Inquiry. 2002; 9(3): 203-14. http://dx.doi.org/10.1046/j.1440-1800.2002.00147.x
[57] Beedholm PK. Forandring og træghed i den sygeplejefaglige diskurs. [Change and inertia in the discourse of nursing]. København: Københavns Universitet; 2003.

[58] Schoot TPI, Legius M, ter Meulen R, et al. Client-Centered Home Care. Balancing between Competing Responsibilities. Clinical Nursing Research. 2006; 15(4): 231-54. PMid:17056768 http://dx.d oi.org/10.1177/1054773806291845

[59] Solbrekke TD. Professional responsibility as legitimate compromisesfrom communities of education to communities of work. Studies in Higher Education. 2008; 33(4): 485-500. http://dx.doi.org/1 $0.1080 / 03075070802211877$

[60] Edwards A. Being an Expert Professional Practitioner: The Relational Turn in Expertise. Dordrecht: Springer Netherlands; 2010. 